\title{
A Study of Radiation Incidence Angle in Cervical Vertebra Anteroposterior(AP) Examination by Position
}

\author{
Jonghyeok Kwak \\ Depart of Radiology, Pusan National University Hospital \\ 자세에 따른 목뼈 정면 입사각에 대한 연구 \\ 곽종혁 \\ 부산대학교병원 영상의학과
}

\begin{abstract}
In anteroposterior radiation test for cervical vertebra, it is general that the incidence angle of X-ray is $15^{\circ}$ to $20^{\circ}$ degrees to head regardless of position. So this study suggests appropriate incidence angle of cervical vertebra depended on the position.

From 1 January 2013 to 31 December 2013, cervical spine radiographys and magnetic resonance imaging was performed in 107 people who visited P Hospital located in Pusan. Among them, 39 people(men 24, women 15) were below 80 above 20 years old(average age 54 years) with normal cervical lordosis(normal $40^{\circ} \pm 5^{\circ}$ ). In erect position, the incidence angle of cervical vertebra is measured from lateral radiographic images. And in supine position, it measured from MRI sagittal images.

Results based on gender, the incidence angle of cervical vertebra in erect position was $25.9^{\circ}$ for men, women was $23.1^{\circ}$, showed statistically significant $(\mathrm{p}<0.05)$. And the angle in supine was $11.6^{\circ}$ for men, women was $12.6^{\circ}$, showed not statistically significant $(\mathrm{p}>0.05)$

An analysis of age group shows, the incidence angle of cervical vertebra in erect position was $24.6^{\circ}$ under 50 , and $25.0^{\circ}$ over 50 . The angle in supine was $12.0^{\circ}$ under 50 , and $11.9^{\circ}$ over 50 . And all of them showed not statistically significant $(\mathrm{p}>0.05)$. At all ages, the average of incidence angles in erect position were $24.8^{\circ}$, and the angle in supine was $12.0^{\circ}$, showed statistically significant $(\mathrm{p}<0.05)$.

The cervical vertebra incidence angle for X-ray was $15^{\circ}$ to $20^{\circ}$ degrees to head in general. But, through the results, it is recommended that the angle is $24.8^{\circ}$ in erect and $12.0^{\circ}$ in supine position. It could be shown true anteroposterior(AP) view of cervical vertebra and accurate intervertebral fusion fixing devices.
\end{abstract}

Keyword : Radiation Incidence Angle in Anteroposterior Cervical Vertebra, Cervical Lordosis angles, Intervertebral disc angles

\section{요 야}

통상적으로 사용되는 목뼈 정면 입사각은 자세에 상관없이 머리 쪽으로 $15^{\circ} \sim 20^{\circ}$ 의 입사각으로 촬영이 이루어지고 있으며 자세의 구분 없이 일률적으로 입사각을 사용하고 있으므로 자세에 따라 달라지는 목뼈의 추간판각을 측정하여 
적정한 목뼈 정면 입사각을 제시하고자 하였다. 2013년 1월 1일부터 2013년 12월 31일까지 부산의 P대학병원을 내원 한 목뼈 단순촬영 및 자기공명영상을 시행한 107 명의 검사자 중 목뼈 전만각(정상 $40^{\circ} \pm 5^{\circ}$ )이 정상적인 20 세 이상 80 세 이하(평균연령 54 세) 39 명(남자 24 명, 여자 15 명)을 대상으로 선 자세는 목뼈 단순촬영 측면영상의 추간판각을 측 정하였으며 누운 자세는 자기공명영상의 가운데 시상면영상의 추간판각을 측정하였고 성별로 분석한 결과를 보면 선 자세의 전체 목뼈 정면입사각은 남자는 $25.9^{\circ}$, 여자는 $23.1^{\circ}$ 로 나타났고 통계적으로 유의하였으며 $(\mathrm{p}<0.05)$, 성별로 분 석한 누운 자세의 전체 목뼈 정면입사각은 남자는 $11.6^{\circ}$, 여자가 $12.6^{\circ}$ 로 나타났으며 통계적으로 유의하지 않았 고,(p>0.05) 연령별로 분석한 결과는 선자세의 전체 목뼈 정면입사각은 50 세 미만이 $24.6^{\circ}, 50$ 세 이상에서 $25.0^{\circ}$ 로 나 타났으며 누운 자세의 목뼈 정면 입사각은 50 세 미만이 $12.0^{\circ}, 50$ 세 이상에서 $11.9^{\circ}$ 로 나타났으며 통계적으로 유의하 지 않았고,( $\mathrm{p}>0.05)$ 선 자세와 누운 자세의 전체 목뼈 정면입사각의 결과는 선 자세에서는 $24.8^{\circ}$ 로 나타났으며 누운 자세에서는 $12.0^{\circ}$ 로 나타났고 통계적으로 유의하였다. $(\mathrm{p}<0.05)$ 연구의 결과를 볼 때 선 자세 및 누운 자세의 목뼈 정 면 입사각은 종전의 머리 쪽으로 $15^{\circ} \sim 20^{\circ}$ 가 아닌 각각 선 자세는 $24.8^{\circ}$, 누운 자세는 $12.0^{\circ}$ 가 추천되며 이로써 각각의 목뼈 추간판각에 따른 정확한 정면 목뼈와 추간원판의 구조 및 수술 후 각각의 목뼈 유합 수술환자 기구파악 및 정확 한 위치를 나타내고 평가할 수 있다고 사료된다.

중심단어: 목뼈 정면 입사각, 전만각, 추간판각

\section{INTRODUCTION}

인체의 기본적인 구조는 뼈대(skeleton)로 이루어져 이중 목뼈는 척추의 중요한 부분으로 머리뼈를 지지 하고 생체 역학적으로 일상생활 동작에서 운동성을 제공하는 기능이 있으며 목뼈부가 장애를 일으키게 되면 머리, 목, 상지 등의 많은 부분에 증상을 나타낼 수 있다 ${ }^{[1]}$. 목뼈는 일곱 개의 뼈로 이루어져 있으며 여 덟 개의 신경을 가지고 있다. 목뼈의 신경은 경수라고 하는데 이 경수는 각각의 부위 마다 불안정 균형으로 인해 통증과 연관이 있다리.

목뼈 질환의 병리학적인 원인은 명백하지는 않지만, 여러 자세에서 머리를 고정시키기 위해 근 수축이 유 지되어야 하며, 근 약화로 인한 피로는 만성적인 목뼈 통증을 일으키는 원인으로 언급되고 있다 ${ }^{[3]}$. 만성 목 뼈 통증은 현대사회에서 유행처럼 증가하고 있는 질 환으로 특히 운전하기, 책상에서 공부하기, 컴퓨터에 서 일하기 등 앉은 자세에서 목을 구부리거나 목을 많 이 움직이게 되므로 목뼈 추간 추체 간 비정상적인 움 직임으로 인한 과 사용으로 근육이 피로를 적절히 조 절하지 못 할 때 목뼈 통증을 유발시키고 ${ }^{[4]}$ 현대인의 운동 부족에 의한 목뼈부의 과도로 과부하의 지속적 인 스트레스 그리고 잘못된 습관과 불량한 자세 그리 고 사고로 인한 많은 병변들이 목뼈부에서 발생한다 ${ }^{[5]}$.

Bench는 측면 목뼈 방사선 사진을 이용하여 연령이
증가함에 따라 목뼈가 전방으로의 만곡이 증가하고, 각 목뼈간의 간격이 감소하여 척추골이 뚜렷해진다고 하였다 ${ }^{[6]}$.

일반적으로 목뼈 골형성증은 단순 방사선 검사에서 는 진단이 가능하지만, 임상적으로는 증상이 나타나지 않는다. 일반 엑스선 검사에서 노화에 의한 척추의 변 성은 60 세 이상 노인에서 $97 \%$ 에서 발견이 되었고, 척 추의 변성에 의한 관절염의 증상을 나타내는 환자의 경우 여자의 $25 \%$ 에서 변성 변화를 나타내고, 남자의 $50 \%$ 에서 척추의 변성 변화를 나타낸다고 보고 하였다 [7]. 이러한 목뼈에 대한 검사 방법은 단순 방사선검사, 전산화단층검사(Computed tomography: CT), 자기공명 영상(Magnetic resonance imaging MRI), 혈관조영술 (Angiography) 등 여러 가지 방법이 있다 ${ }^{[8]}$. 단순 방사 선검사는 목뼈검사 중에서 다른 검사방법과 비교하여 쉽게 영상을 획득하고 저렴한 가격에 비하여 많은 양 의 정보를 가지고 있어서, 목뼈검사에서 기본적이며 꼭 필요한 검사 중의 하나이다. 현재 영상의학과 장비 의 발달로 인하여 일반 방사선검사를 대체하는 검사 법도 많이 개발되고 있다. 하지만 수술 전후 추적검사 시 매우 유용하며 응급실환자의 경우, 빠른 시간에 탈 구나, 골절 등을 진단 시 좋은 검사 방법이다 ${ }^{[9]}$.

목뼈검사에서 측면 검사는 척추골의 배열, 외상 질 환에 의한 탈구, 염증이나 종양 등의 병변유무 등을 관 찰하기 쉽고 한눈에 보기 유용하여 정면상보다 측면상 이 진단적 가치가 높다고 할 수 있다 ${ }^{[10]}$. 목뼈 정면검사 
에서 상부목뼈의 경우 뒤통수뼈와 아래턱뼈와 중복 되 는 일도 많이 있지만, 목뼈의 척추골의 배열, 척추골의 간격, 루시카 관절(Luschka joint)의 형태학적 변화를 관찰 할 수 있는 것을 보면 목뼈 정면검사도 소홀히 해 서는 안 될 것이다 ${ }^{[11]}$.

통상적으로 사용되는 목뼈 정면 입사각은 자세에 상관없이 머리 쪽으로 $15^{\circ} \sim 20^{\circ}$ 의 입사각도로 촬영이 이루어지고 있으며 누운 자세와 선 자세의 구분 없이 일률적으로 입사각을 사용하고 있다. 임상에서 직접 목뼈 단순정면 검사를 해보면 기존의 $15^{\circ} \sim 20^{\circ}$ 의 입사 각도로 촬영을 하면 선자세의 영상은 목뼈가 앞으로 굽혀져서 아래턱뼈가 제 1 번 목뼈와 제 2 번 목뼈 및 상 부척추골이 많이 중복되어 영상의 나타나며 누운 자 세의 영상은 목뼈가 뒤로 펼쳐짐으로서 뒤통수뼈가 제1번 목뼈와 제2번 목뼈 및 상부척추골이 많이 중복 되어 영상의 질 및 진단적 정보를 떨어뜨린다. 따라서 본 연구의 목적은 자세에 따라 달라지는 목뼈의 추간 판각을 측정하여 적정한 목뼈 정면 입사각을 제시하 여 영상의 질 및 진단적 정보를 향상시키고자 본 연구 를 시행하였다.

\section{MATERIAL AND METHOD}

\section{1. 연구대상}

2013년 1월 1일부터 2013년 12월 31일까지 부산의 P 대학병원을 내원한 목뼈 단순촬영 및 자기공명영상을 시행한 107 명의 검사자 중 선자세의 목뼈 전만각(정상 $40^{\circ} \pm 5^{\circ}$ )이 정상적인 20세 이상 80 세 이하(평균연령 54 세) 39 명(남자 24명, 여자 15명)을 대상으로 후향적 연 구를 시행하였다.

Table 1. General characteristics of the study subjects and cervical lordosis

\begin{tabular}{cccccc}
\hline $\begin{array}{c}\text { Demo- } \\
\text { graphics }\end{array}$ & Division & $\mathrm{N}$ & $\begin{array}{c}\text { Percent } \\
(\%)\end{array}$ & $\begin{array}{c}\text { Erect } \\
\text { cervics } \\
\text { lordosis }\end{array}$ & $\begin{array}{c}\text { Supine } \\
\text { cervics } \\
\text { lordosis }\end{array}$ \\
\hline \multirow{2}{*}{ Sex } & Male & 24 & 61.5 & 40.0 & 37.7 \\
& Female & 15 & 38.5 & 39.0 & 30.6 \\
\hline \multirow{2}{*}{ Age } & $50<$ & 14 & 35.9 & 40.2 & 40.0 \\
& $50>$ & 25 & 64.1 & 39.3 & 36.1 \\
\hline \multicolumn{2}{c}{ Total } & 39 & 100 & 39.6 & 35.0 \\
\hline
\end{tabular}

\section{2. 연구방법}

\section{1 측정 방법 및 통계학적 분석}

목뼈 추간판각 측정은 선 자세는 목뼈 단순촬영 측면 영상의 추간판각을 측정하였으며 누운 자세는 자기공명 영상의 가운데 시상면영상의 추간판각을 측정하였다. 본 연구에서는 SPSS 18.0 for windows 통계 패키지 프로 그램을 사용하여 자료 분석하였고 표본의 일반적 특성 은 기술통계를 하였으며 연구의 목적에 부합되도록 대 응표본 T-test 및 독립표본 T-test 등을 시행하였다.

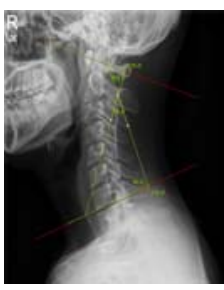

Fig.1.

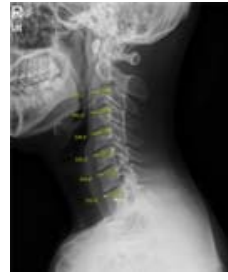

Fig.2.

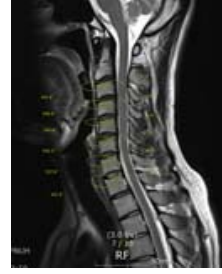

Fig.3.
목뼈의 전만각(Cervical lordosis)은 Figure 1에서 보 이듯이 제 1 번 목뼈(환추)와 제 7 번 목빼(융추)의 척추골 면의 수직선들이 형성하는 목뼈의 전만각도를 말하며 정상범위는 $40^{\circ} \pm 5^{\circ}$ 이다.

선자세의 목뼈 추간판각 측정은 목뼈 단순촬영 측 면영상의 추간판각을 측정하였으며 Figure 2에서 보 이는 바와 같이 목뼈의 상단면과 수평면이 교차하는 각을 계측하여 측정하였다.

누운 자세의 목뼈 추간판각 측정은 자기공명영상 의 가운데 시상면영상의 추간판각을 측정하였으며 Figure 3에서 보이는 바와 같이 목뼈의 상단면과 수평 면이 교차하는 각을 계측하여 측정하였다.

\section{2 사용기기}

본 연구에서 사용한 장비는 선 자세의 목뼈영상을 획득하기 위해서 디지털 엑스선 발생장치(Philips Digital diagnost Eleva Netherland)를 사용하였으며 누운 자세의 목뼈영상을 획득하기 위해서는 자기공명영상 장치(Siemens Avanto 1.5T Germany)를 사용하였다. 목 뼈의 전만각도 및 각각의 추간판각을 측정하기 위하 여 M-view(Infinite ver.52)을 사용하여 측정하였다. 


\section{RESULT}

\section{1. 연구인자의 기술통계 및 $\mathrm{T}$-test 결과}

\section{1 성별 선 자세 목뼈 추간판각의 기술통계 및 독립표본 T-test 결과}

Table 2. Sex position of the cervical intervertebral disc line each descriptive statistics and independent samples T-test results

\begin{tabular}{cccccc} 
& & & \multicolumn{3}{c}{$($ Mean $\pm S D, p<0.05)$} \\
\hline $\begin{array}{c}\text { Radio- } \\
\text { graphic } \\
\text { Landmark }\end{array}$ & Male & Female & Total & $\begin{array}{c}F- \\
\text { value }\end{array}$ & $\begin{array}{c}p- \\
\text { value }\end{array}$ \\
\hline C2-C3 & $20.4 \pm 4.4$ & $16.9 \pm 4.5$ & $19.1 \pm 4.7$ & 0.169 & 0.021 \\
C3-C4 & $23.3 \pm 3.3$ & $20.0 \pm 4.4$ & $22.0 \pm 4.0$ & 0.802 & 0.013 \\
CA-C5 & $25.5 \pm 2.9$ & $22.1 \pm 3.8$ & $24.2 \pm 3.6$ & 0.914 & 0.004 \\
C5-C6 & $26.7 \pm 3.2$ & $24.0 \pm 4.1$ & $25.7 \pm 3.8$ & 0.824 & 0.028 \\
C6-C7 & $28.5 \pm 3.3$ & $24.5 \pm 7.1$ & $27.6 \pm 3.5$ & 2.073 & 0.025 \\
C7-T1 & $31.0 \pm 3.0$ & $29.4 \pm 3.4$ & $30.4 \pm 3.2$ & 0.003 & 0.118 \\
\hline Total & $25.9 \pm 4.8$ & $23.1 \pm 5.6$ & $24.8 \pm 5.3$ & 4.016 & 0.000 \\
C-Spine & & & & &
\end{tabular}

성별로 분석한 table 2 의 결과를 보면 각각의 추간판각 은 남자가 $\mathrm{C} 2-\mathrm{C} 3$ 에서 $20.4^{\circ} \pm 4.4, \mathrm{C} 3-\mathrm{C} 4$ 에서 $23.3^{\circ} \pm 3.3$, $\mathrm{C} 4-\mathrm{C} 5$ 에서 $25.5^{\circ} \pm 2.9, \mathrm{C} 5-\mathrm{C} 6$ 에서 $26.7^{\circ} \pm 3.2, \mathrm{C} 6-\mathrm{C} 7$ 에서 $28.5^{\circ} \pm 3.3, \mathrm{C} 7-\mathrm{T} 1$ 에서 $31.0^{\circ} \pm 3.0$ 로 나타났고 여자는 $\mathrm{C} 2-\mathrm{C} 3$ 에서 $16.9^{\circ} \pm 4.5, \mathrm{C} 3-\mathrm{C} 4$ 에서 $20.0^{\circ} \pm 4.4, \mathrm{C} 4-\mathrm{C} 5$ 에서 $22.1^{\circ} \pm 3.8, \quad \mathrm{C} 5-\mathrm{C} 6$ 에서 $24.0^{\circ} \pm 4.1, \quad \mathrm{C} 6-\mathrm{C} 7$ 에서 $24.5^{\circ} \pm 7.1$, $\mathrm{C} 7-\mathrm{T} 1$ 에서 $29.4^{\circ} \pm 3.4$ 로 나타났으며 성별로 분석한 선자 세의 전체 목뼈 추간판각은 남자는 $25.9^{\circ} \pm 4.8$, 여자는 23.1 ${ }^{\circ} \pm 5.6$ 로 나타났고 통계적으로 유의하였다. $(\mathrm{p}<0.05)$

\section{2 성별 누운 자세 목뼈 추간판각의 기술통계 및 독립표본 T-test 결과}

Table 3. Sex supine position of each cervical disc descriptive statistics and independent samples T-test results

\begin{tabular}{cccccc} 
& & \multicolumn{4}{c}{ (Mean $\pm S D, p<0.05)$} \\
\hline $\begin{array}{c}\text { Radio- } \\
\text { graphic } \\
\text { Landmark }\end{array}$ & Male & Female & Total & $\begin{array}{c}F- \\
\text { value }\end{array}$ & $\begin{array}{c}p- \\
\text { value }\end{array}$ \\
\hline C2-C3 & $7.5 \pm 4.4$ & $9.0 \pm 5.1$ & $8.0 \pm 4.7$ & 0.043 & 0.331 \\
C3-C4 & $8.6 \pm 4.8$ & $10.2 \pm 5.8$ & $9.2 \pm 5.2$ & 0.119 & 0.367 \\
CA-C5 & $9.0 \pm 5.1$ & $11.7 \pm 6.9$ & $10.1 \pm 6.0$ & 0.473 & 0.174 \\
C5-C6 & $11.1 \pm 5.2$ & $12.3 \pm 6.6$ & $11.6 \pm 5.7$ & 1.088 & 0.550 \\
C6-C7 & $15.5 \pm 4.5$ & $15.0 \pm 6.0$ & $15.2 \pm 5.1$ & 1.303 & 0.745 \\
C7-T1 & $17.7 \pm 5.6$ & $17.5 \pm 7.1$ & $17.6 \pm 6.1$ & 1.249 & 0.898 \\
\hline Total & $11.6 \pm 6.2$ & $12.6 \pm 6.7$ & $12.0 \pm 6.4$ & 1.482 & 0.240 \\
C-Spine & & & & & \\
\hline
\end{tabular}

성별로 분석한 Table 3의 결과를 보면 누운 자세의 각각의 추간판각은 남자가 $\mathrm{C} 2-\mathrm{C} 3$ 에서 $7.5^{\circ} \pm 4.4, \mathrm{C} 3-\mathrm{C} 4$ 에서 $8.6^{\circ} \pm 4.8, \mathrm{C} 4-\mathrm{C} 5$ 에서 $9.0^{\circ} \pm 5.1, \mathrm{C} 5-\mathrm{C} 6$ 에서 $11.1^{\circ} \pm 5.2$, C6-C7에서 $15.5^{\circ} \pm 4.5, \mathrm{C} 7-\mathrm{T} 1$ 에서 $17.7^{\circ} \pm 5.6$ 로 나타났고 여자는 $\mathrm{C} 2-\mathrm{C} 3$ 에서 $9.0^{\circ} \pm 5.1, \mathrm{C} 3-\mathrm{C} 4$ 에서 $10.2^{\circ} \pm 5.8, \mathrm{C} 4-\mathrm{C} 5$ 에서 $11.7^{\circ} \pm 6.9, \mathrm{C} 5-\mathrm{C} 6$ 에서 $12.3^{\circ} \pm 6.6, \mathrm{C} 6-\mathrm{C} 7$ 에서 $15.0^{\circ}$ $\pm 6.0, \mathrm{C} 7-\mathrm{T} 1$ 에서 $17.5^{\circ} \pm 7.1$ 로 나타났으며 성별로 분석 한 누운 자세의 전체 목뼈 추간판각은 남자는 $11.6^{\circ}$ \pm 6.2 , 여자가 $12.6^{\circ}$ 로 나타났고 통계적으로 유의하지 않았다. $(\mathrm{p}>0.05)$

\section{3 연령별 선 자세 목뼈 추간판각의 기술통계 및 독립표본 T-test 결과}

Table 4. Age erect position of each cervical disc descriptive statistics and independent samples T-test results

\begin{tabular}{cccccc} 
& & \multicolumn{4}{c}{$($ Mean $\pm S D, p<0.05)$} \\
\hline $\begin{array}{c}\text { Radio- } \\
\text { graphic } \\
\text { Landmark }\end{array}$ & $50 K$ & $50 \geq$ & Total & $\begin{array}{c}F- \\
\text { value }\end{array}$ & $\begin{array}{c}p- \\
\text { value }\end{array}$ \\
\hline C2-C3 & $18.3 \pm 4.2$ & $19.5 \pm 5.0$ & $19.1 \pm 4.7$ & 0.287 & 0.460 \\
C3-C4 & $21.7 \pm 2.9$ & $22.2 \pm 4.6$ & $22.0 \pm 4.0$ & 1.692 & 0.672 \\
C4-C5 & $23.9 \pm 3.0$ & $24.3 \pm 4.0$ & $24.2 \pm 3.6$ & 1.781 & 0.763 \\
C5-C6 & $25.4 \pm 3.0$ & $25.8 \pm 4.2$ & $25.7 \pm 3.8$ & 1.749 & 0.720 \\
C6-C7 & $27.3 \pm 2.2$ & $27.8 \pm 4.1$ & $27.6 \pm 3.5$ & 5.445 & 0.688 \\
C7-T1 & $30.8 \pm 2.3$ & $30.2 \pm 3.7$ & $30.4 \pm 3.2$ & 2.037 & 0.600 \\
\hline $\begin{array}{c}\text { Total } \\
\text { C-spine }\end{array}$ & $24.6 \pm 4.9$ & $25.0 \pm 5.5$ & $24.8 \pm 5.3$ & 1.773 & 0.565 \\
\hline
\end{tabular}

연령별로 분석한 Table 4의 결과를 보면 선자세의 각각의 추간판각은 50 세 미만이 C2-C3에서 $18.3^{\circ} \pm 4.2$, C3-C4에서 21.7 $\pm 2.9, \mathrm{C} 4-\mathrm{C} 5$ 에서 $23.9^{\circ} \pm 3.0, \mathrm{C} 5-\mathrm{C} 6$ 에서 $25.4^{\circ} \pm 3.0, \mathrm{C} 6-\mathrm{C} 7$ 에서 $27.3^{\circ} \pm 2.2, \mathrm{C} 7-\mathrm{T} 1$ 에서 $30.8^{\circ} \pm 2.3$ 로 나타났고 50 세 이상에서는 $\mathrm{C} 2-\mathrm{C} 3$ 에서 $19.5^{\circ} \pm 5.0, \mathrm{C} 3-\mathrm{C} 4$ 
"J. Korean Soc. Radiol., Vol. 9, No. 2, February 2015"

에서 $22.2^{\circ} \pm 4.6, \mathrm{C} 4-\mathrm{C} 5$ 에서 $24.3^{\circ} \pm 4.0, \mathrm{C} 5-\mathrm{C} 6$ 에서 $25.8^{\circ}$ 土4.2, C6-C7에서 $27.8^{\circ} \pm 4.1, \mathrm{C} 7-\mathrm{T} 1$ 에서 $30.2^{\circ} \pm 3.7$ 로 나타 났으며 연령별로 분석한 선자세의 전체 목뼈 추간판 각은 50 세 미만이 $24.6^{\circ} \pm 4.9,50$ 세 이상에서 $25.0^{\circ} \pm 5.5$ 로 나타났고 통계적으로 유의하지 않았다. $(\mathrm{p}>0.05)$

\section{4 연령별 누운 자세 목뼈 추간판각의 기술통계 및 독립표본 T-test 결과}

Table 5. Age supine position of each cervical disc descriptive statistics and independent samples T-test results

\begin{tabular}{cccccc}
\multicolumn{1}{c}{50} & \multicolumn{3}{c}{$($ Mean $\pm S D, p<0.05)$} \\
\hline $\begin{array}{c}\text { Radio- } \\
\text { graphic } \\
\text { Landmark }\end{array}$ & $50 K$ & $50 \geq$ & Total & $\begin{array}{c}F- \\
\text { value }\end{array}$ & $\begin{array}{c}p- \\
\text { value }\end{array}$ \\
\hline C2-C3 & $8.5 \pm 5.8$ & $7.8 \pm 4.0$ & $8.0 \pm 4.7$ & 3.626 & 0.677 \\
C3-C4 & $9.2 \pm 6.1$ & $9.2 \pm 4.7$ & $9.2 \pm 5.2$ & 1.693 & 0.984 \\
C4-C5 & $9.0 \pm 6.8$ & $10.6 \pm 5.5$ & $10.1 \pm 6.0$ & 0.545 & 0.417 \\
C5-C6 & $10.9 \pm 5.4$ & $11.9 \pm 5.9$ & $11.6 \pm 5.7$ & 0.244 & 0.620 \\
C6-C7 & $15.9 \pm 4.2$ & $14.9 \pm 5.5$ & $15.2 \pm 5.1$ & 1.384 & 0.547 \\
C7-T1 & $18.4 \pm 6.3$ & $17.2 \pm 6.1$ & $17.6 \pm 6.1$ & 0.088 & 0.543 \\
\hline Total & $12.0 \pm 6.8$ & $11.9 \pm 6.2$ & $12.0 \pm 6.4$ & 1.732 & 0.949 \\
C-spine & & & & &
\end{tabular}

연령별로 분석한 Table 5의 결과를 보면 누운 자세 의 각각의 추간판각은 50 세 미만이 C2-C3에서 $8.5^{\circ}$

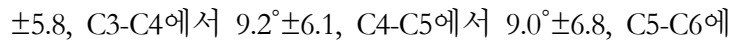
서 $10.9^{\circ} \pm 5.4, \mathrm{C} 6-\mathrm{C} 7$ 에서 $15.9^{\circ} \pm 4.2, \mathrm{C} 7-\mathrm{T} 1$ 에서 $18.4^{\circ} \pm 6.3$ 로 나타났고 50 세 이상에서는 $\mathrm{C} 2-\mathrm{C} 3$ 에서 $7.8^{\circ} \pm 4.0$, $\mathrm{C} 3-\mathrm{C} 4$ 에서 $9.2^{\circ} \pm 4.7, \mathrm{C} 4-\mathrm{C} 5$ 에서 $10.6^{\circ} \pm 5.5, \mathrm{C} 5-\mathrm{C} 6$ 에서 $11.9^{\circ} \pm 5.9, \mathrm{C} 6-\mathrm{C} 7$ 에서 $14.9^{\circ} \pm 5.5, \mathrm{C} 7-\mathrm{T} 1$ 에서 $17.2^{\circ} \pm 6.1$ 로 나타났으며 연령별로 분석한 누운 자세의 전체 목뼈 추간판각은 50 세 미만이 $12.0^{\circ} \pm 6.8,50$ 세 이상에서 $11.9^{\circ}$ \pm 6.2 로 나타났고 통계적으로 유의하지 않았다. $(\mathrm{p}>0.05)$

\section{5 선 자세 및 누운 자세 목뼈 추간판각의 기술통 계 및 대응표본 T-test 결과}

Table 6. Standing position and supine position of each cervical disc descriptive statistics and paired sample T-test results

\begin{tabular}{ccccc} 
& & & \multicolumn{2}{c}{$($ Mean $\pm S D, p<0.05)$} \\
\hline $\begin{array}{c}\text { Radiographic } \\
\text { Landmark }\end{array}$ & Erect & Supine & $\begin{array}{c}T- \\
\text { value }\end{array}$ & $\begin{array}{c}\mathrm{p}- \\
\text { value }\end{array}$ \\
\hline C2-C3 & $19.1 \pm 4.7$ & $8.0 \pm 4.7$ & 11.429 & 0.000 \\
C3-C4 & $22.0 \pm 4.0$ & $9.2 \pm 5.2$ & 13.227 & 0.000 \\
C4-C5 & $24.2 \pm 3.6$ & $10.1 \pm 6.0$ & 13.756 & 0.000 \\
C5-C6 & $25.7 \pm 3.8$ & $11.6 \pm 5.7$ & 13.171 & 0.000 \\
C6-C7 & $27.6 \pm 3.5$ & $15.2 \pm 5.1$ & 13.755 & 0.000 \\
C7-T1 & $30.4 \pm 3.2$ & $17.6 \pm 6.1$ & 12.600 & 0.000 \\
\hline Total & $24.8 \pm 5.3$ & $12.0 \pm 6.4$ & 12.06 & 0.000 \\
C-spine & & & & \\
\hline
\end{tabular}

자세별로 분석한 Table 6의 결과를 보면 선 자세에 서 각각의 추간판각은 $\mathrm{C} 2-\mathrm{C} 3$ 에서 $19.1^{\circ} \pm 4.7, \mathrm{C} 3-\mathrm{C} 4$ 에서 $22.0^{\circ} \pm 4.0, \mathrm{C} 4-\mathrm{C} 5$ 에서 $24.2^{\circ} \pm 3.6, \mathrm{C} 5-\mathrm{C} 6$ 에서 $25.7^{\circ} \pm 3.8$, C6-C7에서 $27.6^{\circ} \pm 3.5, \mathrm{C} 7-\mathrm{T} 1$ 에서 $30.4^{\circ} \pm 3.2$ 로 나타났고 누운 자세의 각각의 추간판각은 $\mathrm{C} 2-\mathrm{C} 3$ 에서 $8.0^{\circ} \pm 4.7$, C3-C4에서 9.2 $\pm 5.2, \mathrm{C} 4-\mathrm{C} 5$ 에서 $10.1^{\circ} \pm 6.0, \mathrm{C} 5$-C6에서 $11.6^{\circ} \pm 5.7, \mathrm{C} 6-\mathrm{C} 7$ 에서 $15.2^{\circ} \pm 5.1, \mathrm{C} 7-\mathrm{T} 1$ 에서 $17.6^{\circ} \pm 6.1$ 로 나타났으며 자세별로 분석한 전체 목뼈 추간판각의 결과는 선 자세에서는 $24.8^{\circ} \pm 5.3$ 로 나타났고 누운 자세 에서는 $12.0^{\circ} \pm 6.4$ 로 나타났으며 통계적으로 유의하였 다. $(\mathrm{p}<0.05)$

\section{DISCUSSION AND CONCLUSION}

본 연구는 자세에 따라 달라지는 목뼈 전만 각 및 각각의 추간판각을 측정하여 적정한 정면 입사각을 제시하고자 본 연구를 시행하였다. 2013년 1월 1일부 터 2013년 12월 31일까지 부산의 P대학병원을 내원한 목뼈 단순촬영 및 자기공명영상을 시행한 107 명의 검 사자 중 목뼈 전만각(정상 $40^{\circ} \pm 5^{\circ}$ )이 정상적인 20 세 이 상 80세 이하(평균연령 54세) 39명(남자 24명, 여자 15 명)을 대상으로 후향적 연구를 시행하였다. 목뼈 추간 판각 측정은 선 자세는 목뼈 단순촬영 측면영상의 추 간판각을 측정하였으며 누운 자세는 자기공명영상의 가운데 시상면영상의 추간판각을 측정하였다.

현대의학의 발전으로 평균수명과 기대 수명이 늘어 나고 고령화 사회가 형성이 되면서 퇴행성 질환에 대 한 관심이 많아지고 있다. 목뼈의 퇴행성은 25 세 이후 부터 시작이 되어 60 세 이상은 약 $80 \%$ 가 방사선 검사 
에서 퇴행성 질환을 가지고 있다 ${ }^{[12]}$. 목뼈의 퇴행성 증 상의 가장 큰 변화는 추간원판의 변성이다. 목뼈의 추 간원판의 높이는 퇴행성 질환을 평가하는데 중요한 지표가 되는데, 정상인의 추간원판의 높이는 퇴행성 질환을 평가하는데 중요한 지표가 되는데, 정상인의 추간원판의 간격은 남자는 $18.5 \mathrm{~mm}$, 여자는 $17.5 \mathrm{~mm}$ 이 고 정상 성인의 평균치는 약 $17.0 \mathrm{~mm}$ 이다 ${ }^{[13]}$.

목뼈의 전만각 측정은 기존의 연구 ${ }^{[14]}$ 와 같은 방법 으로 제 1 번 목뼈(환추)와 제 7 번 목뼈(융추)의 척추골 면의 하연에 평행하게 직선을 긋고 두 개의 선의 이루 는 각도를 측정하였다. 정상인의 정상적인 목뼈 전만 각도는 $40^{\circ} \pm 5^{\circ}$ 를 이룬다 ${ }^{[15]}$. 선자세의 목뼈 추간판각 측정은 목뼈 단순촬영 측면영상의 추간판각을 측정하 였으며 목뼈의 상단 면과 수평면이 교차하는 각을 계 측하여 측정하고 누운 자세의 목뼈 추간판각 측정은 자기공명영상의 가운데 시상면영상의 추간판각을 측정 하였으며 목뼈의 상단 면과 수평면이 교차하는 각을 계측하여 측정하였다 ${ }^{[15]}$.

여러 연구자들은 목뼈 정면 검사의 입사각을 제시 하고 있지만, 자세에 따른 표준화된 정면 입사각이 확 립되지 않아 논문마다 각기 다른 입사각을 자료로 제 시하고 있다. Boylston은 전후 사 방향 검사 시 발쪽으 로 $15^{\circ} \sim 20^{\circ}$ 입사각을 주어 검사를 시행 할 것을 주장 하였으며, Jacobi는 입사각을 머리 쪽으로 $15^{\circ}$ 를 주장 하였으며, Sante는 머리 쪽으로 $20^{\circ}$ 을 주장하고, 市川은 머리 쪽으로 $10^{\circ}$ 를 주장하고 있다 ${ }^{[16]}$. 앞에서 하지만 자세에 따른 입사각을 따로 구분한 논문은 없었다. 따라서 본 연구에서의 자세에 따른 목뼈 정면 입사각 을 측정한 결과를 분석해 보면 다음과 같다.

성별로 분석한 결과를 보면 각각의 목뼈의 추간판 각은 남자가 $\mathrm{C} 2-\mathrm{C} 3$ 에서 $20.4^{\circ}, \mathrm{C} 3-\mathrm{C} 4$ 에서 $23.3^{\circ}, \mathrm{C} 4-\mathrm{C} 5$ 에서 $25.5^{\circ}, \mathrm{C} 5-\mathrm{C} 6$ 에서 $26.7^{\circ}, \mathrm{C} 6-\mathrm{C} 7$ 에서 $28.5^{\circ}, \mathrm{C} 7-\mathrm{T} 1$ 에 서 $31.0^{\circ}$ 로 나타났고 여자는 $\mathrm{C} 2-\mathrm{C} 3$ 에서 $16.9^{\circ}, \mathrm{C} 3-\mathrm{C} 4$ 에 서 $20.0^{\circ}, \mathrm{C} 4-\mathrm{C} 5$ 에서 $22.1^{\circ}, \mathrm{C} 5-\mathrm{C} 6$ 에서 $24.0^{\circ}, \mathrm{C} 6-\mathrm{C} 7$ 에서 $24.5^{\circ}, \mathrm{C} 7-\mathrm{T} 1$ 에서 $29.4^{\circ}$ 로 나타났으며 성별로 분석한 선 자세의 전체 목뼈 추간판각은 남자는 $25.9^{\circ}$, 여자는 $23.1^{\circ}$ 로 나타났고 남자가 여자보다 약 $2^{\circ}$ 정도 높게 나타 났으며 통계적으로 유의하였다. $(\mathrm{p}<0.05)$ 성별로 분석한 누 운 자세의 각각의 추간판각은 남자가 $\mathrm{C} 2-\mathrm{C} 3$ 에서 $7.5^{\circ}$, $\mathrm{C} 3-\mathrm{C} 4$ 에서 $8.6^{\circ}, \mathrm{C} 4-\mathrm{C} 5$ 에서 $9.0^{\circ}, \mathrm{C} 5-\mathrm{C} 6$ 에서 $11.1^{\circ}, \mathrm{C} 6-\mathrm{C} 7$
에서 $15.5^{\circ}, \mathrm{C} 7-\mathrm{T} 1$ 에서 $17.7^{\circ}$ 로 나타났고 여자는 C2-C3 에서 $9.0^{\circ}, \mathrm{C} 3-\mathrm{C} 4$ 에서 $10.2^{\circ}, \mathrm{C} 4-\mathrm{C} 5$ 에서 $11.7^{\circ}, \mathrm{C} 5-\mathrm{C} 6$ 에서 $12.3^{\circ}, \mathrm{C} 6-\mathrm{C} 7$ 에서 $15.0^{\circ}, \mathrm{C} 7-\mathrm{T} 1$ 에서 $17.5^{\circ}$ 로 나타났으며 성별로 분석한 누운 자세의 전체 목뼈 추간판각은 남 자는 $11.6^{\circ}$, 여자가 $12.6^{\circ}$ 로 나타났고 남자가 여자보다 $1{ }^{\circ}$ 정도 낮게 나타났으며 통계적으로 유의하지 않았 다.(p>0.05)

연령별로 분석한 결과는 선자세의 각각의 목뼈의 추간판각은 50 세 미만이 $\mathrm{C} 2-\mathrm{C} 3$ 에서 $18.3^{\circ}, \mathrm{C} 3-\mathrm{C} 4$ 에서 $21.7^{\circ}, \mathrm{C} 4-\mathrm{C} 5$ 에서 $23.9^{\circ}, \mathrm{C} 5-\mathrm{C} 6$ 에서 $25.4^{\circ}, \mathrm{C} 6-\mathrm{C} 7$ 에서 $27.3^{\circ}$, $\mathrm{C} 7-\mathrm{T} 1$ 에서 $30.8^{\circ}$ 로 나타났고 50 세 이상에서는 $\mathrm{C} 2-\mathrm{C} 3$ 에 서 $19.5^{\circ}, \mathrm{C} 3-\mathrm{C} 4$ 에서 $22.2^{\circ}, \mathrm{C} 4-\mathrm{C} 5$ 에서 $24.3^{\circ}, \mathrm{C} 5-\mathrm{C} 6$ 에서 25.8, C6-C7에서 $27.8^{\circ}, \mathrm{C} 7-\mathrm{T} 1$ 에서 $30.2^{\circ}$ 로 나타났으며 연령별로 분석한 선자세의 전체 목뼈 추간판각은 50 세 미만이 $24.6^{\circ}, 50$ 세 이상에서 $25.0^{\circ}$ 로 나타났고 통계적 으로 유의하지 않았다. $(\mathrm{p}>0.05)$ 연령별로 분석한 누운 자세의 각각의 추간판각은 50 세 미만이 C2-C3에서 $8.5^{\circ}$, C3-C4에서 9.2 , C4-C5에서 9.0 , C5-C6에서 10.9 , C6-C7 에서 $15.9^{\circ}, \mathrm{C} 7-\mathrm{T} 1$ 에서 $18.4^{\circ}$ 로 나타났고 50 세 이상에서 는 $\mathrm{C} 2-\mathrm{C} 3$ 에서 $7.8^{\circ}, \mathrm{C} 3-\mathrm{C} 4$ 에서 $9.2^{\circ}, \mathrm{C} 4-\mathrm{C} 5$ 에서 $10.6^{\circ}$, C5-C6에서 $11.9^{\circ}, \mathrm{C} 6-\mathrm{C} 7$ 에서 $14.9^{\circ}, \mathrm{C} 7-\mathrm{T} 1$ 에서 $17.2^{\circ}$ 로 나타났으며 연령별로 분석한 누운 자세의 전체 목뼈 추간판각은 50 세 미만이 $12.0^{\circ}, 50$ 세 이상에서 $11.9^{\circ}$ 로 나타났고 통계적으로 유의하지 않았다. $(\mathrm{p}>0.05)$

자세별로 분석한 결과는 선 자세의 각각의 목뼈의 추간판각은 $\mathrm{C} 2-\mathrm{C} 3$ 에서 $19.1^{\circ}, \mathrm{C} 3-\mathrm{C} 4$ 에서 $22.0^{\circ}, \mathrm{C} 4-\mathrm{C} 5$ 에 서 $24.2^{\circ}, \mathrm{C} 5-\mathrm{C} 6$ 에서 $25.7^{\circ}, \mathrm{C} 6-\mathrm{C} 7$ 에서 $27.6^{\circ}, \mathrm{C} 7-\mathrm{T} 1$ 에서 $30.4^{\circ}$ 로 나타났고 누운 자세의 각각의 추간판각은 $\mathrm{C} 2-\mathrm{C} 3$ 에서 $8.0^{\circ}, \mathrm{C} 3-\mathrm{C} 4$ 에서 $9.2^{\circ}, \mathrm{C} 4-\mathrm{C} 5$ 에서 $10.1^{\circ}, \mathrm{C} 5-\mathrm{C} 6$ 에서 $11.6^{\circ}, \mathrm{C} 6-\mathrm{C} 7$ 에서 $15.2^{\circ}, \mathrm{C} 7-\mathrm{T} 1$ 에서 $17.6^{\circ}$ 로 나타났 으며 자세별로 분석한 전체 목뼈 추간판각의 결과는 선 자세에서는 $24.8^{\circ}$ 로 나타났고 누운 자세에서는 $12.0^{\circ}$ 로 나타났으며 선자세가 누운 자세보다 약 $13^{\circ}$ 정도 높 게 나타났으며 통계적으로 유의하였다. $(\mathrm{p}<0.05)$

연구의 제한점으로는 연구 특성상 첫째로, 누운 자 세의 목뼈 측면영상을 자기공명영상에 기초하여 추간 판각을 측정하였다는 점을 들 수 있고 두 번째로 연구 대상자의 연령분포가 20 세 이상 80 세 이하로 제한됨에 따라 결과 값을 소아에게는 적용하기 어렵다는 점을 들 수 있으며 셋째로 1 년간의 목뼈 단순영상촬영 및 
자기공명영상을 검사한 107 명의 대상자 중 목뼈 전만 각이 정상인 연구 대상자 수가 39 명으로 적었다는 점 을 들 수 있겠다.

연구의 결과를 볼 때 선 자세 및 누운 자세의 목뼈 정면 입사각은 종전의 머리 쪽으로 $15^{\circ} \sim 20^{\circ}$ 가 아닌 각 각 선 자세는 $24.8^{\circ}$, 누운 자세는 $12.0^{\circ}$ 가 추천되며 이로 써 각각의 목뼈 추간판 각도에 따른 정확한 정면 목뼈 와 추간원판의 구조 및 수술 후 각각의 목뼈 유합 수 술환자 기구파악 및 정확한 위치를 나타내고 평가할 수 있다고 사료된다.

\section{Reference}

[1] Greenman PE, "Principles of Medicine", Williams \& Wilkins, USA, Vol. 2, 1996.

[2] Baek SH, "Basic human anatomy," Seoul : Nursing Association, 1994.

[3] Calliet R, "Neck and Arm Pain,", FA Davis, 1991.

[4] Heo JK, "The Impact of Static Strength and Static Endurance of the Neck Deep Flexor on Chronic Neck Pain.", Korea sport research, 2005.

[5] Kim MJ, "The effect of the Medx therapeutic exercise on cervical extensor muscle strength and pain scale for the patient,", Yongin University Master's Thesis, 2000.

[6] Bench RM. "Growth of the cervical vertebrae as related tongue, face, and the denture behavior.", Am J Orthod Dent facial Orthop Vol. 49, pp183-214, 1963.

[7] Lim Young "Radiographic Measurement of Normal Adult Cervical Spinal Region in the Korean Population,", The journal of the korean orthopedic association, Vol. 22, No.1, 1987.

[8] Shin MJ, "Imaging of the Cervical Spine.", Journal of korean society of spine surgery, Vol. 6, No. 2, 1999.

[9] Jeung SW, "A Study of Radiation Incidence Angle in Anteroposterior Cervical Vertebra Examination.", Hanseo University Master's Thesis, 2012.

[10] Jeung HR, "Textbook of Radiography Position and Clinical Diagnosis.", Chung Ku Public, pp.244-245, 2002.

[11] Osamu W, "Study of Central X-Ray Incidence Angle of Antero-Posterior Projection in Radiography of the Cervical spine", Nov 15, 1999.

[12] Kim SH, "A review of degenerative changes in the inter vertebral disc", The journal of Korean Society of Physical
Therapy, Vol. 15, No. 2, 2003.

[13] Kim WJ, "Imaging findings and clinical study on patientswho suffer from cervical pain.", Yongin University Master's Thesis, 2002.

[14] Lee SH, Yu YS, Woo I, Ha IH, "Investingation on the Relationship Scoliotic Curve and BMI, Cervical Lordosis Lumar Lordosis and Ferguson Angle in Spinal Scoliosis Patient". The Journal of Korea CHUNA Manual Medicine for spine \&nerves, Vol. 1, No. 2, 2006.

[15] Kang MC, "Radiographic Measurement of Spinal Region", Kim Hae Sung-Mo Hospital Radiology.

[16] Heo J, "Cervical Vertebral Foramen Method”, Korea Hyeon Ki Sul, Vol. 4, No. 1, pp.81, 1973. 